\title{
IMPLEMENTATION OF PHYSICAL EDUCATION LEARNING OUTCOMES ASSESSMENT IN THE 2013 CURRICULUM
}

\author{
Novri Gazali ${ }^{1}$, Romi Cendra ${ }^{2}$, Hafid Dwi Saputra ${ }^{3}$, \\ Ahmad Rahmadani ${ }^{4}$, Feby Elra Perdima ${ }^{5}$ \\ Universitas Islam Riau ${ }^{1,2,3,4}$, Universitas Dehasen Bengkulu ${ }^{5}$ \\ novri.gazali@edu.uir.ac.id
}

\begin{abstract}
Curriculum implementation is one of the most important problems in the curriculum cycle. The purpose of this study was to determine the implementation of the 2013 curriculum in physical education learning in the aspect of assessing learning outcomes at Cendana High School Pekanbaru. This study uses a qualitative research approach, where the researcher is the key instrument. The data collected in this qualitative study was carried out in a natural setting, the data collection techniques were mostly at the time of observation, primary data sources, and interviews and documentation. The research subjects taken in this study were only 1 school principal and 1 physical education teacher at Cendana High School Pekanbaru City. This data analysis includes three stages, namely data reduction, data display, and drawing conclusions. Based on the results of the study, the conclusions obtained in this study are: the teacher has implemented the 2013 curriculum in physical education learning in the aspect of assessing learning outcomes at Cendana High School Pekanbaru City is in accordance with the applicable curriculum, the implementation can be seen based on the RPP compiled mostly based on the 2013 curriculum, the implementation of learning is also good, as can be seen from the learning process that has used a scientific approach and an integrated thematic approach.
\end{abstract}

Keywords: Curriculum; evaluation; learning outcomes; physical education

Accepted: $24^{\text {th }}$ of January 2022

Correspondence author: Novri Gazali, Universitas Islam Riau, Indonesia. E-Mail: novri.gazali@edu.uir.ac.id DOI http://dx.doi.org/10.31851/hon.v5i1.6352 doi

\section{(c) (i) (2)}

Jurnal Halaman Olahraga Nusantara licensed under a Creative Commons Attribution-ShareAlike 4.0 International License

\section{INTRODUCTION}

In education in Indonesia, physical education has been included in the curriculum and is a subject that must be completed at every level of compulsory education (Oktriyeni, 2019). In the education unit, physical education learning is incorporated into the 2013 curriculum (Aryanti et al., 2021). Curriculum implementation is one of the most important problems in the curriculum cycle (Alshammari, 2013; Aytan, 2016; Suyanto, 2018). The curriculum is very important, because it is needed in formulating the main objectives of the learning 
Novri Gazali, Romi Cendra, Hafid Dwi Saputra, Ahmad Rahmadani, Feby Elra Perdima, (2022)

process in each country (Mustafa, 2020). Each educational unit will adjust the characteristics of the curriculum in accordance with the standards and policies of the institution by considering the suitability of the capabilities of human resources, facilities, social conditions and existing financing. (Sholichin, Saifudin, $\&$ Buana, 2019). The curriculum in Indonesia has undergone several changes (Rahmawati, 2018). The new curriculum now is the 2013 curriculum and is implemented in the odd semester of the school year 2013/2014 (Irianto, 2014).

Physical education is a key area of learning in the curriculum that focuses on developing the skills and movement concepts that students need to participate in physical activities with competence and confidence (Lynch, 2019). There have been many researchers from various countries who have studied the curriculum in physical education learning (Alfrey \& O'Connor, 2020; Santos, Neves, Pereira, \& Cardoso 2020; Zhang, Wang, Yli-Piipari, \& Chen, 2020). Especially regarding the 2013 curriculum in physical education learning in Indonesia, many researchers discuss it (Irianto, 2014; Mustafa, 2020; Wajdi \& Jamaluddin, 2019; Wardhana et al., 2017; Yane, 2013).

The 2013 curriculum research on physical education learning tends to discuss the implementation of the 2013 curriculum in physical education learning in elementary schools (Irianto, 2014; Suherman, 2014), in senior high school (Wajdi \& Jamaluddin, 2019), in high school (Wajdi \& Jamaluddin, 2019), problems with the design of physical education assessments in the 2013 curriculum in high school (Mustafa, 2021), evaluation of the implementation of the 2013 curriculum in physical education lessons in junior high school (Alaswati et al., 2016; Wardhana et al., 2017), implementation of a scientific approach to learning physical education, sports and health (Rahmat et al., 2019). However, researchers have not found the implementation of the 2013 curriculum in physical education learning in Pekanbaru City, especially at Cendana High School Pekanbaru. 
Novri Gazali, Romi Cendra, Hafid Dwi Saputra, Ahmad Rahmadani, Feby Elra Perdima, (2022)

Jendral A. Yani Street Lorong Gotong Royong 9/10 Ulu Palembang South Sumatera

Accredited

JURALJHUKGLIMRAGAH email jurnal: jurnalhon@univpgri-palembang.ac.ic SINTA 3

Based on the problems that the researchers encountered, there are still schools that have not implemented the 2013 curriculum perfectly in Pekanbaru City, because many teachers complain in conducting the assessment process. Assessment is one aspect that has undergone many changes in the 2013 curriculum (Mufid et al., 2020). Taking into account the weaknesses of the previous curriculum, K13 emphasizes a holistic assessment that covers the cognitive, affective, and psychomotor domains and is carried out with tests that are equipped with a portfolio (Mulyasa, 2018; Setiadi, 2016). Moreover, the assessment of learning outcomes based on the 2013 Curriculum is carried out on a competency basis, strengthening the Benchmark Reference Assessment (PAP), as well as being carried out on basic competencies (KD), core competencies (KI), and graduate competency standards (SKL) (Hakim, 2017).

Therefore, researchers are interested in conducting research and looking at the implementation of the 2013 curriculum, especially in the assessment aspect. Through this research, it is hoped that SMA Cendana Pekanbaru can find out how far it has implemented the 2013 curriculum, and the school can fix problems with the recommendations of researchers. The purpose of this study is to determine the implementation of the 2013 curriculum in physical education learning in the aspect of assessing learning outcomes at Cendana High School Pekanbaru.

\section{METHOD}

This study uses a qualitative research approach, where the researcher is the key instrument. The data collected in this qualitative study was carried out in a natural setting, the data collection techniques were mostly at the time of observation, primary data sources, and interviews and documentation. The research subjects taken in this study were only one school principal and one physical education teacher at Cendana High School Pekanbaru City. This data analysis includes three stages, namely data reduction, data display, and drawing conclusions. 
Novri Gazali, Romi Cendra, Hafid Dwi Saputra, Ahmad Rahmadani, Feby Elra Perdima, (2022)

\section{RESULT AND DISCUSSION}

The implementation of learning based on the 2013 curriculum which has been required by the government and implemented gradually in every school in Indonesia, to realize the objectives of the 2013 curriculum. The following are the results of interviews in research:

\section{Principal Interview Results on Implementation of 2013 Curriculum Learning Outcomes Assessment on Physical Education Learning at Cendana High School Pekanbaru}

Based on the analysis of interviews and documentation with physical education teachers and the Principal of Cendana High School Pekanbaru that has been carried out, the lesson plans are made by themselves using the guidelines contained in the module. The following is an explanation from the Principal of Cendana High School Pekanbaru. when asked about the implementation of the 2013 curriculum in physical education learning in the assessment aspect at Cendana High School Pekanbaru.

a) In assessing spiritual attitudes, does the physical education teacher use an assessment observation sheet?

+ "For the 2013 curriculum, for attitude assessment we do have an assessment rubric".

b) Is the assessment instrument on spiritual attitudes in the form of a journal?

+ "For this spiritual activity, especially for physical education, indeed in this assessment, there is already a journal, because the teacher is required to assess students, the teacher must use a journal".

c) In assessing social attitudes, do physical education teachers use assessment observation sheets?

+ "still related to the first one, everything has a rubric, starting from the spiritual, social and attitude"

d) Is the assessment instrument on social attitudes in the form of a journal?

+ "because of its social nature there is an assessment format, of course automatically for the assessment of these students there are a lot of things that must be assessed, of course using a journal".

e) Do physical education teachers provide opportunities for students to conduct self-assessment?

+ "both for this attitude assessment, there are lots of rubrics, from the teacher, peer assessment, and from himself". 
Novri Gazali, Romi Cendra, Hafid Dwi Saputra, Ahmad Rahmadani, Feby Elra Perdima, (2022)

HALAMAN Jendral A. Yani Street Lorong Gotong Royong 9/10 Ulu OLAHRAGA

- NUSANTARA email jurnal: jurnalhon@univpgri-palembang.ac.id JURALJUIIKOLIRRAGIA situs web: http://www.univpgri-palembang.ac.id

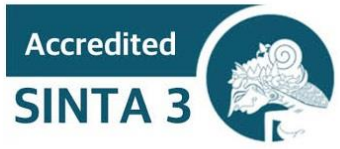

f) Do physical education teachers provide opportunities for students to conduct peer assessments?

+ "As I said earlier, there are a lot of assessments of this attitude, it is hoped that the physical education teacher can assess students well, as well as peer and self-assessment".

g) Has the physical education teacher made a knowledge assessment in the form of a written test?

+ "In the 2013 curriculum, it is now called the Final Semester Assessment or (PAS), so to measure the child's ability of teacher students using cognitive assessment, most of these cognitive assessments are in the form of multiple choice questions and structured essays.

h) Has the physical education teacher made a knowledge assessment in the form of an oral test?

+ "For oral test assessment, in the form of daily tests can be done but for more physical education or tends to psychomotor assessment, have also used oral tests

i) Does the physical education teacher give homework as a form of assessment of the assignment?

+ "one of the end in physical education and in other subjects, after giving a summary, oral test, the teacher also gives assignments at home, so that our children can study at home, as a prerequisite for the continuation of the next lesson"

j) Do physical education teachers conduct performance assessments?

+ "The physical education teacher may have a higher percentage for psychomotor activities to $75 \%$ for psychomotor activities or practical assignments, according to the question it is clear, because the physical education subject teacher emphasizes more on how the stages of movement in sports movements are"

\section{Interview Results on Implementation of Curriculum 2013 in Physical Education Learning at Cendana High School Pekanbaru}

Then the following are the results of the interview with the Physical

Education teacher at Cendana High School Pekanbaru:

a) In assessing spiritual attitudes, did you use an assessment observation sheet?

+ "of course in the assessment of student attitudes using observation sheets so that the assessment of students becomes valid".

b) Is your assessment instrument on spiritual attitude in the form of a journal?

+ "according to the 2013 Curriculum we have used journals, only we have just used learning journals".

c) In the assessment of social attitudes, did you use an assessment observation sheet? 
+ "everything in the 2013 Curriculum kit uses an assessment sheet".

d) Is your assessment instrument on social attitudes in the form of a journal? + "same as before on attitude, honesty, discipline by also using a journal where the assessment has positive and negative values".

e) Do you provide opportunities for students to do self-assessment? + "Usually the assessment is based on the value of oneself and his friends, of course we have a scope of assessment. For example, A judges B, when A makes a move, $\mathrm{B}$ will see and give an assessment, as well as after changing roles.

f) Do you provide opportunities for students to conduct peer assessments? + "This is the assessment, where students pair up with their friends in doing the assessment".

g) Have you made a knowledge assessment in the form of a written test?

"That's for sure, every time we need to do a written test, in the form of questions that can be essays and can also be objective.

h) Have you made a knowledge assessment in the form of an oral test?

+ "We also did an oral test, we called students one by one, then they were given 5 questions, then graded".

i) Do you give homework as a form of assessment of the assignment?

+ "Yes, almost every meeting we provide material, in the form of a portfolio so that students have assignments at home".

j) Did you do a performance appraisal?

+ "performance? That is psychomotor assessment, of course we do a psychomotor assessment on physical education, because one of the assessments is an assessment of performance in sports, for example in athletics, how to start correctly, when running and how to enter the finish line."

From the implementation of the assessment using the 2013 curriculum in learning physical education at SMA Cendana Pekanbaru, it has been carried out in accordance with the syllabus and lesson plans that have been prepared by the physical education teacher. Teachers have tried their best to be able to implement the 2013 curriculum so that learning objectives can be achieved. It's just that when the learning process in certain materials is still not optimal because of the constraints of inadequate learning media, both in the form of the availability of sufficient sports equipment, as well as the condition of the facilities in the field that are not well maintained. 
Novri Gazali, Romi Cendra, Hafid Dwi Saputra, Ahmad Rahmadani, Feby Elra Perdima, (2022)

From the results of the interviews above, the teacher still applies the results of the assessment based on observations made at that time. In accordance with the spiritual attitude assessment instruments, social attitudes, written and oral test assessments as well as the provision of enrichment have been carried out in accordance with the 2013 curriculum and have used learning journals.

This study aims to determine the implementation of the 2013 curriculum in physical education learning in the aspect of assessing learning outcomes at Cendana High School Pekanbaru. Based on the results of this study, the teacher administration has tried to implement the 2013 curriculum quite well, especially in the aspect of student assessment. This is in accordance with the findings of Wardhana et al., (2017) that the implementation and implementation of the 2013 curriculum on the standard of assessment has gone very well at the State Junior High School 6 Malang. Whereas Akbar et al., (2020) explained that the daily assessment instrument for psychomotor aspects made by educators of Physical Education, Sports and Health subjects in Banjarbaru City was in the strong category. Next Sofyan and Kuntjoro (2021) explained that the implementation of the assessment system for the subjects of Physical Education, Sports, and Health at the Mriyunan State Elementary School in Gresik Regency had gone very well. However, the problems faced by many teachers in implementing the 2013 curriculum are assessments (Rahmawati, 2018).

Based on the results of this study, of course, it means that the implementation of the assessment aspects of physical education learning in the 2013 curriculum at Cendana High School Pekanbaru has gone quite well, it's just that teachers still need to learn a lot and get used to using the 2013 curriculum, by adding teaching experience and innovating learning methods.

\section{CONCLUSION}

Based on the results of the study, the conclusions obtained in this study are: the teacher has implemented the 2013 curriculum in physical education learning in the aspect of assessing learning outcomes at Cendana High School 
Novri Gazali, Romi Cendra, Hafid Dwi Saputra, Ahmad Rahmadani, Feby Elra Perdima, (2022)

Pekanbaru City is in accordance with the applicable curriculum, the implementation can be seen based on the RPP compiled mostly already based on the 2013 curriculum, the implementation of learning is also good, as can be seen from the learning process that has used a scientific approach and an integrated thematic approach.

This research is only limited to the aspect of assessment with 1 school. It is hoped that further researchers will be able to continue this research with a large number of samples and add other aspects such as planning learning programs and the process of implementing learning.

\section{REFERENCES}

Akbar, M. A., Rahmadi, \& Mulhim. (2020). Intrumen Penilaian Harian Aspek Psikomotor Pendidikan Jasmani Olahraga dan Kesehatan M. Jurnal Pendidikan Jasmani Dan Olahraga, 1(1), 56-62.

Alaswati, S., Rahayu, S., \& Raffy Rustiana, E. (2016). Evaluasi Pelaksanaan Pembelajaran Kurikulum 2013 PJOK. Journal of Physical Education and Sports, 5(2), 111-119.

Alfrey, L., \& O'Connor, J. (2020). Critical pedagogy and curriculum transformation in Secondary Health and Physical Education. Physical Education and Sport Pedagogy, 25(3), 288-302. https://doi.org/10.1080/17408989.2020.1741536

Alshammari, A. (2013). Curriculum Implementation and Reform: Teachers' Views About Kuwait's New Science Curriculum. US-China Education Review, 3(3), 181-186.

Aryanti, Si., Solahuddin, S., \& Azhar, S. (2021). Learning Forehand Service Badminton Using Teaching Games for Understanding (TGFU) Students. Halaman Olahraga Nusantara (Jurnal Ilmu Keolahragaan), 4(2), 305-317. https://doi.org/10.31851/hon.v4i25675

Aytan, T. (2016). Evaluation of the 2006 and 2015 Turkish Education Program in Secondary School Curriculum in Turkey in Terms of Critical Thinking. Journal of Education and Learning, 5(2), 38. https://doi.org/10.5539/jel.v5n2p38

Hakim, L. (2017). Analisis Perbedaan Antara Kurikulum KTSP dan Kurikulum 
Novri Gazali, Romi Cendra, Hafid Dwi Saputra, Ahmad Rahmadani, Feby Elra Perdima, (2022)

HALAMAN Jendral A. Yani Street Lorong Gotong Royong 9/10 Ulu OLAHRAGA Palembang South Sumatera
2013.
Jurnal
Ilmiah
Didaktika,
$17(2)$
$280-292$.
https://doi.org/10.22373/jid.v16i1.590

Irianto, T. (2014). Implementasi Kurikulum 2013 dalam Pembelajaran Pendidikan Jasmani Olahraga dan Kesehatan di Sekolah Dasar. Jurnal Multilateral, 13(1), 58-61.

Lynch, T. (2019). Physical education and wellbeing: Global and holistic approaches to child health. In Physical Education and Wellbeing. Palgrave Macmillan. https://doi.org/10.1007/978-3-030-22266-6

Mufid, M. K. A. W., Purnomo, A., \& Adi, K. R. (2020). Implementation of Skills Assessment Based on the 2013 Curriculum on Social Science Subject. Jurnal Evaluasi Pendidikan, 11(1), 7-16. https://doi.org/10.21009/JEP.0111.02

Mulyasa, H. E. (2018). Pengembangan dan implementasi kurikulum 2013. Remaja Rosdakarya.

Mustafa, P. S. (2020). Kontribusi Kurikulum Pendidikan Jasmani, Olahraga, dan Kesehatan di Indonesia dalam Membentuk Keterampilan Era Abad 21. Jurnal Pendidikan: Riset dan Konseptual, 4(3), 437-452. https://doi.org/10.28926/riset_konseptual.v4i3.248

Mustafa, P. S. (2021). Problematika Rancangan Penilaian Pendidikan Jasmani, Olahraga, dan Kesehatan dalam Kurikulum 2013 pada Kelas XI SMA. Edumaspul: Jurnal Pendidikan, 5(1), 184-195. https://doi.org/https://doi.org/10.33487/edumaspul.v5i1.947

Oktriyeni, H. (2019). Kecerdasan gerak dalam pendidikan jasmani. Halaman Olahraga Nusantara (Jurnal Ilmu Keolahragaan), 2(2), 167-176.

Rahmat, R., Suwardi, S., \& Suyudi, I. (2019). Implementasi Pendekatan Saintifik Pada Pembelajaran Pendidikan Jasmani Olahraga dan Kesehatan (PJOK) SD Kurikulum 2013 Di Kabupaten Bantaeng. SPORTIVE: Journal Of Physical Education, Sport and Recreation, 2(2), 63. https://doi.org/10.26858/sportive.v2i2.9502

Rahmawati, A. N. (2018). Identifikasi Masalah yang Dihadapi Guru dalam Penerapan Kurikulum 2013 Revisi di SD. Indonesian Journal of Primary Education, 2(1), 114. https://doi.org/10.17509/ijpe.v2i1.14227

Santos, F., Neves, R., Pereira, P., \& Cardoso, A. (2020). The physical education curriculum and life skills: Processes and intervention strategies | O currículo de educacąõ física e as life skills: Processos e estratégias de intervencąõ. 
Novri Gazali, Romi Cendra, Hafid Dwi Saputra, Ahmad Rahmadani, Feby Elra Perdima, (2022)

Accredited

SINTA 3

Motricidade, 16(2), 135-143. https://doi.org/10.6063/motricidade.18931

Setiadi, H. (2016). Pelaksanaan penilaian pada Kurikulum 2013. Jurnal Penelitian Dan Evaluasi Pendidikan, 20(2), 166-178. https://doi.org/10.21831/pep.v20i2.7173

Sholichin, R., Saifudin, A., \& Buana, V. G. (2019). Dynamics of Use of Methods And Teaching Books in TPQ Learning Under The Ring of LP. Ma'arif in Garum, Blitar. Journal of Development Research, 3(1), 31-36. https://doi.org/10.28926/jdr.v3i1.66

Sofyan, M., \& Kuntjoro, B. F. T. (2021). Studi Implementasi Sistem Penilaian Terhadap Mata Pelajaran Pendidikan Jasmani Olahraga dan Kesehatan Pada Sekolah Inklusi di Kabupaten Gresik. JPOK, 9(1), 37-42.

Suherman, A. (2014). implementasi Kurikulum Baru Tahun 2013 Mata Pelajaran Pendidikan Jasmani. Mimbar Sekolah Dasar, 1(1), 71-76.

Suyanto, S. (2018). The Implementation of the Scientific Approach Through 5MS of the Revised Curriculum 2013 in Indonesia. Cakrawala Pendidikan, 37(1), 22-29. https://doi.org/10.21831/cp.v37i1.18719

Wajdi, R., \& Jamaluddin, J. (2019). Studi Tentang Implementasi Kurikulum 2013 Pada Guru Mata Pelajaran Pendidikan Jasmani, Olahraga dan Kesehatan. SPORTIVE: Journal of Physical Education, Sport and Recreation, 2(2), 79. https://doi.org/10.26858/sportive.v2i2.9504

Wardhana, S. A., Asim, A., \& Widijoto, H. (2017). Evaluasi Pelaksanaan Kurikulum 2013 Pada Mata Pelajaran Pendidikan Jasmani Olahraga dan Kesehatan di SMPN 6 Malang Dengan Menggunakan Analisis Swot. Gelanggang Pendidikan Jasmani Indonesia, 1(1), 87. https://doi.org/10.17977/um040v1i1p87-102

Yane, S. (2013). Perkembangan Kurikulum SMP/Mts Mata Pelajaran Pendidikan Jasmani (Analisis Kurikulum 1975-2006). Jurnal Edukasi, 11(2), 229-239. https://journal.ikippgriptk.ac.id/index.php/edukasi/article/view/218

Zhang, T., Wang, Y., Yli-Piipari, S., \& Chen, A. (2020). Power of the Curriculum: Content, Context, and Learning in Physical Education. Research Quarterly for Exercise and Sport. https://doi.org/10.1080/02701367.2020.1768202 